Secondly, Newton was responsible for the introduction of the deductive method in the natural sciences and so rendered signal service to mankind as the founder of mathematical physics, which has been the basis of so much in science for two and a half centuries. Then, his rational mechanics had a profound influence for many generations. Newton's differential equations showed how the state of the universe today is the result of all its past history, and its future history could be determined by its present. This required a strict determinism which obsessed the minds of men of science for a long period, though in comparatively recent times there has been a strong reaction against it. His work on optics showed his ability as an experimental physicist. Newton's subordination of optics to mechanies, far from enhancing progress, was a principal cause of the lack of progress in optics during the eighteenth century. An ironical result of his experiments with diffraction and interference was the death-knell a century later of his corpuscular theory of light. Lastly, Newton's philosophical work must not be forgotten. Space and time were objective and independent of our perception of them, according to Newton, and were not a priori representations which served for the foundations of all external intuitions. Force, energy, mass, motion, as well as space and time, were all objective entities for Newton. His work must be considered a model of the systematic application of scientific mothoda model of the power of reason to investigate the natural, controlling and ruling it, by placing it at the service of progress, material, cultural and moral, of humanity.

\section{Earthquakes Recorded during September}

The U.S. Coast and Geodetic Survey has determined the epicentres of six earthquakes occurring between Sept. 5 and 20 . The first was on Sept. 5 from lat. $0^{\circ}$ long. $125^{\circ} \mathrm{E}$., which is in the Molucca Passage east of the island of Celebes in the East Indies; time at origin, $8 \mathrm{~h} .34 \cdot 8 \mathrm{~m}$. The second was on Sept. 6 from an epicentre lat. $53 \cdot 2^{\circ} \mathrm{S}$. long. $159 \cdot 4^{\circ} \mathrm{E}$., which is north-east of the Macquarie Islands, south-west of New Zealand; time at origin, $3 \mathrm{~h} .41 \cdot 5 \mathrm{~m}$. The third was on Sept. 10 from an epicentre lat. $18 \cdot 9^{\circ} \mathrm{N}$. long. $67^{\circ} \mathrm{W}$., which is near the north-west coast of Porto Rico in the West Indies, time at origin being $2 \mathrm{~h} .31 \cdot 6 \mathrm{~m}$. The fourth was also on Sept. 10, from an epicentre near lat. $35 \cdot 1^{\circ} \mathrm{N}$. long. $133 \cdot 3^{\circ} \mathrm{E}$., which is in the Pacific Ocean west of California, time at origin being $8 \mathrm{~h} .36 \cdot 9 \mathrm{~m}$. The fifth was on Sept. 11, from an epicentre near lat. $16 \frac{1}{2}^{\circ} \mathrm{S}$. long. $173^{\circ} \mathrm{W}$., which is in the Pacific Ocean between Samoa and the Friendly Islands and east of Fiji. Time at origin was $19 \mathrm{~h}$. $34 \mathrm{~m}$. The sixth was on Sept. 20 from an epicentre near lat. $19 \frac{1}{2}^{\circ} \mathrm{N}$. long. $109^{\circ} \mathrm{W}$., which is in the Pacific Ocean west of Mexico and north-east of Revilla Gigedo Island. Time at origin was $00 \mathrm{~h} .53 \cdot 7 \mathrm{~m}$.

Earthquakes were registered at Kew on Sept. 5 at $08 \mathrm{~h} .49 \mathrm{~m}$. $11 \mathrm{~s}$. from an epicentre $12,000 \mathrm{~km}$. distant; on Sept. 6 at 04h. 01m. 32s. from an epicentre $18,700 \mathrm{~km}$. distant (maximum amplitude at Kew $440 \mu)$; and on Sept. I0 at $08 \mathrm{~h} .49 \mathrm{~m}$. $32 \mathrm{~s}$. from an epicentre $9,560 \mathrm{~km}$. distant (maximum amplitude $250 \mu$ at Kew). All times are in Universal Time and interpretations and calculations are provisional.

On October 26 an earthquake was felt in San Francisco. Some telephones were put out of action, some windows broken and some articles jolted off shelves.

\section{Announcements}

The title of professor of technical optics in the University of London has been conferred on Dr. L. C. Martin in respect of the post held by him at the Imperial College of Science and Technology.

THE University of Oxford has accepted an offer from the Lord Nuffield Provincial Hospitals Trust of $£ 8,000$ a year for research in plastic surgery and for training in that branch of surgery.

During 1943 the Royal Society of South Africa elected the following fellows : John G. Rose, formerly Government analyst and chief chemist to the S.A. Railways and Harbours, Cape Town, for his valuable applications of chemistry in the field of engineering; and Hillel A. Shapiro, assistant Government pathologist, Cape Town, for his work on experimental physiology and malnutrition. The Abbé Henri E. P. Breuil, the distinguished archæologist, at present attached to the University of the Witwatersrand, Johannesburg, has been elected an honorary fellow of the Society.

The Charles L. Mayer Award for 1943 will be made by the National Science Fund of the U.S. National Academy of Sciences for an outstanding contribution to present-day knowledge of factors affecting the growth of animal cells, with particular reference to human cancer. In addition, the advisory committee requests recommendations from scientific men of persons whose present work is in this field and who are achieving outstanding results. The closing date for the receipt of manuscripts and published articles is January 15, 1944; they should be sent to the National Science Fund of the National Academy of Sciences, 515 Madison Avenue, New York 22, N.Y.

Messra. H. K. Lewis and Co., Ltd., 136 Gower Street, London, W.C.1, have issued a price list of certain German publications which are being repro. duced in the United States by photo-offset process under authorization of the Alien Property Custodian in Washington. It includes books on mathematics, physics and chemistry, mainly published during the period 1930-40; among the titles are many standard works of references, as well as recent technical books. Messrs. Lewis are accepting orders, but anticipate a delay of three months in obtaining copies.

Six popular lectures on astronomy have been arranged by the Royal Astronomical Society and the British Astronomical Association, and are being given on Fridays at the Royal Astronomical Society's rooms in Burlington House, Piccadilly, London, W.l, for members of the British and Allied Forces. The first was given on December 3 by Sir James Jeans on "Photographic Astronomy". On December 17 Prof. W. M. Smart is speaking on "The Origin of the Earth". Succeeding lectures will be given on January 7, by Mr. B. M. Peek, on "The Planets and Planetary Observations" ; on January 21, by Prof. H. Dingle, on "The Movements of the Stars"; on February 4, by Mr. Will T. Hay, on "Life on other Planets"; and on February 18, by Mr. F. J. Har. greaves, on "The Determination of Stellar Distances". The lectures begin at 6.30 p.m. Admission is free by tickets obtainable from Service Organizations or from the Assistant Secretary, Royal Astronomical Society, Burlington House, Piccadilly, London, W.1 